\title{
MEMOIR
}

\section{ROBERT RUTHVEN TILT}

Mr Robert Ruthven Tilt, who died on the I 5 th December, 193 I, at Worthing, in his 69th year, began his insurance career in the year 1882 in the General Life Assurance Company where he held a position in the Actuarial Department, representing in 1894 the Actuary "in his absence." He left the service of this Company in 1895 to take up an appointment with the London Assurance Corporation, where he remained for one year only, leaving to become, in I896, Assistant Actuary of the General Reversionary and Investment Company, Ltd., and Actuary and Secretary in 1905 on the retirement of $\mathrm{Mr} \mathrm{D}$. A. Bumsted. He

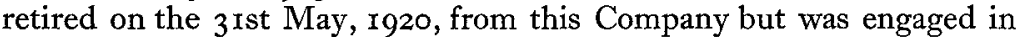
various important consultative capacities which rendered his name familiar to many of the members. Probably Mr Tilt's chief claim to fame as an actuary rests upon his skill in dealing with reversionary investments coupled with considerable mathematical ability.

$\mathrm{Mr}$ Tilt became a Fellow of the Institute of Actuaries by examination in 1891 . He was Tutor for Part II from 1893 to 1896 ; four times an Examiner; Honorary Secretary I9I2-13; Vice-President $1914-17$ and served on the Council for eleven years. He contributed twice to the Proceedings of the Institute, his papers appearing in Vols. XxxII and XLVIII, the latter dealing with the treatment of depreciation of assets, a subject with which he was fully conversant.

Throughout his career he was regarded as an exceptionally gifted and talented man and many business associates will deplore his death.

W. M. J. 